Running head: Iberian ibex range expansion in central Spain

\title{
The Iberian ibex is under an expansion trend but displaced to suboptimal habitats by the presence of extensive goat livestock in central Spain
}

\section{Pelayo Acevedo, Jorge Cassinello* and Christian Gortazar} Instituto de Investigación en Recursos Cinegéticos (IREC), CSIC, UCLM, JCCM

${ }^{*}$ Author for correspondence: Jorge Cassinello Instituto de Investigación en Recursos Cinegéticos (IREC), CSIC, UCLM, JCCM. Ronda de Toledo s/n, 13005 Ciudad Real. Spain

Tel. +34 926 295450, Fax +34 926295451

E-mail: jorge.cassinello@uclm.es 
4 In this paper an updated distribution of the Iberian ibex (Capra pyrenaica

5 Schinz, 1838) in the central Spanish region of Castile - La Mancha is shown.

6 The species is present in $19 \%$ of the study region, and in areas not cited so

7 far in the literature. A detailed analysis of habitat suitability was also carried

8 out, applying a new methodology, Ecological-Niche Factor Analysis, which

9 uses presence data to build a habitat suitability map of a given species. As

10 livestock activity is quite intense in the region, the presence of a potential

11 competitor, the domestic goat (Capra hircus), was included in the analyses.

12 Factors affecting ibex relative abundance were determined by means of a

13 nested stepwise multiple regression, where livestock presence/absence was

14 the nested factor. The presence of livestock has a negative effect on ibex

15 relative abundance, causing the ibex to select areas of poor, sparse

16 vegetation, cultivated lands and forests, whereas in the absence of livestock,

17 the ibex is mainly present in pasture-scrub lands and non-cultivated lands.

18 Conservation implications of these results are discussed in the context of a

19 Mediterranean region where extensive livestock grazing systems abound.

21 Keywords: biodiversity conservation, Capra hircus, Capra pyrenaica, livestock

22 grazing system, habitat displacement, habitat suitability analysis, resource

23 competition 
29 To conservation biologists it is of particular interest to determine the effects of

30 invasive species on the natural history of autochthonous ones (see Lodge

31 1993). A particular example is that of exotic ungulates introduced in areas

32 where they can potentially compete with native ones (see, e.g., Cassinello et

33 al. 2004). Among the former, livestock represent a particular instance (Voeten

34 and Prins 1999), usually underestimated by conservation biologists

35 (Fleischner 1994). Although livestock graze more than one-third of the world's 36 land area, and in many instances share resources with native ungulates (see 37 de Haan et al. 1997), evidences of a negative impact on the latter are not

38 conclusive and highly debated (e.g. Saberwal 1996; Mishra and Rawat 1998;

39 Madhusudan 2004; Young et al. 2005).

41 The development of large, relatively permanent, agriculture-based societies

42 was the primary event initiating livestock domestication about 10,000 years

43 ago (Price 2002). With a few exceptions, ungulate domestication (e.g. cattle,

44 sheep and goats) mainly began in the Near East (Troy et al. 2001). The

45 presence of livestock in Europe goes back to Neolithic times, domestic sheep

46 and goats showing up particularly in Mediterranean countries (see, e.g.,

47 Martín Bellido et al. 2001).

49 The status and distribution of the Iberian ibex have been studied by several

50 authors, either in the whole peninsula (e.g. Granados et al. 2002; Pérez et al.

51 2002) or in some particular areas (e.g. Granados et al. 1998; Palomares and 
52 Ruiz-Martínez 1993; Lasso de La Vega 1994; Pérez et al. 1994; Gortazar et

53 al. 2000). Concerning Castile - La Mancha region, in central Spain, Granados

54 et al. (2002) indicate that the ibex is distributed exclusively in $11 \%$ of the

55 region, whereas Pérez et al. (2002) distinguish 51 ibex population nuclei in

56 Spain, out of which only 4 were located in Castile - La Mancha: Serranía de

57 Cuenca, Cabañeros National Park, Sierra de Alcaraz (connected to the well

58 established ibex population of Sierra de Cazorla, Segura y Las Villas Natural

59 Park, it is supposedly in expansion), and Sierra Madrona (a series of

60 fragmented nuclei connected to other ones in Sierra Morena, Jaén province).

61

62 Here, we analyse the current distribution and habitat use of the Iberian ibex

63 (Capra pyrenaica Schinz 1838) in Castile - La Mancha. We have considered it

64 appropriate to use a political division to define our study area because in

65 Spain conservation field is partly ruled by regional governments. This region is

66 characterized by an intense livestock breeding activity, namely extensive

67 sheep and goat grazing systems (see Martin Bellido et al. 2001). We have,

68 thus, included in our analyses the presence of the domestic goat (Capra

69 hircus), a close relative of the Iberian ibex and, therefore, expected to share

70 feeding habits and ecological requirements with it; to our knowledge, no

71 comparative studies of diet and/or spatial niche use have been made so far.

72 Sheep, on the contrary, show a differing feeding behaviour (Martínez 2002)

73 and probably their potential as competitor of the lberian ibex is less

74 pronounced. 
76 The spatial prediction of species distribution is an important tool for

77 conservation biology and management planning (e.g., Hortal et al. 2005;

78 Whittaker et al. 2005). Developments of ecological and biogeographic theories

79 have been translated into different methodologies, which are able to predict

80 the distribution ranges and habitat suitability of species (see Guisan and

81 Zimmermann 2000; Ferrier et al. 2002; Scott et al. 2002), using a wide variety

82 of statistical approaches and Geographical Information Systems tools (GIS)

83 (e.g., Austin 2002; Rushton et al. 2004). The use of a Digital Elevation Model

84 (DEM) constitutes a basis for generating maps of environmental variables

85 (see Guisan and Zimmermann 2000), as it has basic outcomes, such as

86 altitude, slope or aspect, which influence the distribution of the organisms.

87 Furthermore, the use of digitalised land information database, allows a more

88 detailed analysis of factors determining species distribution.

89

90 Predictive models can easily be made from data of the presence and absence

91 of a given species (e.g., Osborne and Tigar 1992; Brito et al. 1999).

92 Nevertheless, it is necessary to distinguish true absences from a mere lack of

93 information (Thuiller et al. 2004; Araújo et al. 2005). The determination of true

94 absences of a given species in a given area is the main problem of many

95 animal presence/absence data sets (Hirzel et al. 2002; Zaniewski et al. 2002).

96 Thus, some techniques incorporate presence-only data (Hortal et al. 2005),

97 such as the relatively novel Ecological Niche Factor Analysis (ENFA) (Hirzel

98 et al. 2002). ENFA is used to determine habitat suitability starting from the

99 location of presence-only data. These maps are the result of the location of a

100 given species within the multidimensional environmental area that is defined 
by considering all mapping units within the study area (Guisan and Zimmermann 2000). These habitat suitability maps indirectly reveal the species potential distribution (Hirzel et al. 2002). This approach is recommended when absence data are not available (most data banks), unreliable (most cryptic or rare species) or meaningless (invaders) (Hirzel et al. 2001), the subsequent results are to be handled with caution (e.g., Brotons et al. 2004; Engler et al. 2004). Using these data, this method characterizes the realized niche of the species from a set of environmental predictors. Thus, an application of the method could be interesting in many domains: landscape

110 management for endangered species, better knowledge of unknown or

111 inaccessible areas, or also better knowledge of 'new species' ecology and/or

112 distribution (e.g. Reutter et al. 2003; Gallego et al. 2004; Chefaoui et al.

113 2005). This method was originally assessed in the Alpine ibex (Capra ibex)

114 (Hirzel et al. 2002), but is currently widely used (see a list of publications at 115 http://www2.unil.ch/biomapper/bibliography.html).

117 Apart from an updated distribution of the Iberian ibex in Castile - La Mancha, 118 our aim in this study is to carry out a detailed analysis of habitat suitability of 119 the species and determine which factors affect its abundance taking into 120 account the influence of livestock presence/absence. 
127 Located in central Spain, it corresponds with Castile - La Mancha political 128 division (U.T.M. 30S 294,348-681,063 4,208,706-4,575,340), which is placed 129 at the southern plateau of the Iberian Peninsula. Politically, the region is 130 conformed of five provinces (see Figure 1), where the study species is 131 distributed unevenly. Castile - La Mancha is the Iberian region where game 132 activity is more intense. It has a surface area of $79,226 \mathrm{Km}^{2}$, which represents $13315.7 \%$ of the whole Spanish territory. The area devoted to game activity in this 134 region is $70,000 \mathrm{Km}^{2}$ ( $88 \%$ of its territory), big game estates occupying 19,000 $135 \mathrm{Km}^{2}$ (Junta de Comunidades de Castilla - La Mancha, 136 http://www.jccm.es/medioambiente/mednat/cazapesca.htm).

138 The study region shows a typical Mediterranean continental climate, with dry 139 periods both in summer and winter, rains concentrated in autumn and spring, 140 and extreme temperatures during the hottest (summer) and coldest (winter) 141 seasons. Mediterranean woodland vegetation is present and it is formed of 142 oak trees (Quercus ilex) along with shrubs of different species (e.g., Q.

143 coccifera, Pistacia lentiscus, Cistus spp., Rosmarinus officinalis, etc.). Open 144 lands with scattered trees (evergreen oak savannah like habitats), the so145 called "dehesas", are also common. In addition, pine woodlands (Pinus spp.) 146 can also be found in some elevated areas.

148 Apart from the Iberian ibex, other ungulate species that can be found free149 ranging in the study area are wild boar (Sus scrofa) and red deer (Cervus 150 elaphus), and to a lesser extent fallow deer (Dama dama), and roe deer 
151 (Capreolus capreolus) (see, respectively, Rosell and Herrero 2002; Carranza

152 2002; Braza 2002; San José 2002).

153

154 The study species

155

156 The Iberian ibex is a wild goat endemic to the Iberian Peninsula. The IUCN

157 (2004) considered it as at Low Risk, but near threatened (LR/nt), whereas the

158 existing subspecies hold different qualifications. C. p. victoriae Cabrera, 1911

159 is Vulnerable (VU D2), due to the few and small areas it inhabits (see Pérez et

160 al. 2002). C. p. hispanica Shimper, 1848 is at Low Risk (LC/cd), but its viability

161 depends on current conservation programmes. This latter subspecies is

162 widely distributed compared to the former one (ibid). Two other subspecies

163 were also distinguished, but they are extinct nowadays: C. p. pyrenaica

164 Schinz, 1838 and C. p. lusitanica Schlegel, 1872 (ibid). However, the

165 distinction of these subspecies has been questioned by Manceau et al.

166 (1999), who found no genetic differences between the two existing

167 subspecies.

168

169 The sampling method

170

171 Presence of ibexes in the study area was assessed by means of direct field

172 observations and by carrying out surveys $(n=149)$ addressed to forest rangers

173 and staff from environmental agencies of the government of Castile - La

174 Mancha region. Information obtained by other naturalists was verified by 
175

visiting areas where ibexes were reported. The sampling units were $10 \times 10$ km. UTM grid cells $(n=905)$.

Survey addressees were asked to draw in a map their work area and the range occupied by the Iberian ibex, red deer, wild boar and livestock. $A$ questionnaire was given to them, where they indicated the status of the populations present, such as the largest group size registered, a straightforward variable, easy to account for by field watchers.

In order to assess ibex abundance, we firstly relied on forest rangers and environmental managers' indication of the largest group size registered. The Iberian ibex is characterized by sexual segregation through most of the year, but the largest group sizes are attained during the mating season (NovemberDecember) according to Granados (2001), when ibexes are also more conspicuous. We have confirmed that group sizes given in the questionnaire refer to mixed groups observed during the mating season, when they may reflect population abundance in species showing sexual segregation (see Toigo et al. 1996). In addition, we validated these data by carrying out our own field surveys.

During September 2003, we performed 17 field surveys consisting of line transects (e.g., Burnham et al. 1980), a methodology widely used to estimate relative abundance of wild goats (e.g., Alados and Escós 1996; Pérez et al. 1994). Average length of line transects was $3 \mathrm{~km}$., and they were carried out in the main areas where the Iberian ibex is present in Castile - La Mancha, 

and during hours of maximum activity, i.e. at dawn and at dusk (e.g., Alados

201 1986). We only registered female groups, and used these data to test whether

202 the largest group size obtained in the questionnaire was a good estimate of

203 ibex abundance (see Results).

204

205 Habitat suitability

206

207 The ENFA computes a habitat suitability model by comparing the

208 ecogeographical variables (EGVs) which characterize the locations where the

209 species is detected with those present in the whole study area (Hirzel et al.

210 2002).

211

212 Habitat suitability for the Iberian ibex was assessed in the area where the

213 species was more abundant according to the surveys, using $1 \times 1 \mathrm{~km}$ UTM grid

214 cells. Twenty-seven EGVs were defined, including topographical features (e.g.

215 altitude, slope), land cover, and livestock presence (see Table 1), and

216 normalized by a Box-Cox transformation (Sokal and Rohlf 1981). We did not

217 considered climatic variables because of the relative homogeneity of the study

218 area on this matter, where only slight differences can be registered, mainly

219 due to topographic variations. Average distances to each land cover classes

220 were calculated for each sample unit by means of "Distance Operator" tool

221 (Idrisi32 v.32.21) (see Hirzel et al. 2002). The topographic data from a digital

222 elevation model (DEM) carried out by the Shuttle Radar Topography Mission

223 (European Environment Agency 2000), with a spatial resolution of $90 \mathrm{~m}$., was

Table 1 over here 
224 extracted by overlaying the DEM with the cells of $1 \times 1 \mathrm{~km}$. in a geographic

225 information system (Idrisi32 v32.21) (see Hortal et al. 2001).

226

227 Firstly, the ENFA was run, by means of BioMapper software (Hirzel et al.

228 2001; 2004; see http://www.unil.ch/biomapper/). It computes a global

229 marginality coefficient, expressing how, on all the EGVs, the species average

230 differs from the global average, and a global specialization coefficient,

231 expressing the ratio of global variance to species variance.

232

233 Formally, marginality is defined as the absolute difference between the global

234 mean and the species mean, divided by the standard deviations of the global

235 distribution multiplied by a constant (see Hirzel 2001 for details). A value

236 close to one means that the species lives in a very particular habitat relative to

237 the reference set. Similarly, specialization is defined as the ratio of the

238 standard deviation of the global distribution to that of the study species (Hirzel

239 2001). A randomly-chosen set of cells is expected to have a specialization of

240 one, while any value exceeding that score indicates some form of

241 specialization.

242

243 The factor coefficients for the marginality factor account for the marginality of

244 a given species in each EGV considered. It is measured as units of standards

245 deviations of the global distribution. The higher the absolute value of a

246 coefficient, the further the species departs from the average value of a given

247 EGV. There are other factors which express a degree of specialization, where 
248 the higher the value, the more restricted is the range of the study species on

249 the corresponding variable (Hirzel 2001).

250

251 Habitat use

252

253 Information obtained from the surveys was registered in $10 \times 10 \mathrm{~km}$. UTM grid

254 squares $(n=905)$ by means of Idrisi32 v32.21 software (Clark Labs, Clark

255 University). For each UTM square the frequency of occurrence of 11

256 ecogeographical variables (EGVs) were identified (see Table 2). These

257 variables were obtained from CORINE Land Use/Land Cover database,

258 spatial resolution (pixel width) of 250 m. (European Environment Agency

259 1996). From this information we carried out both the habitat use analysis and

260 the study of the influence of goat livestock.

262 The analysis of the variables which determine habitat use (Table 2) by the

263 Iberian ibex was assessed by a nested stepwise multiple regression analysis,

264 using domestic goats presence/absence as the nested factor (e.g. Quinn and

265 Keough 2002). The Iberian ibex abundance was the response variable. We

266 designed a three step procedure to clarify the significance of the variables and

267 their interaction with goat livestock on the Iberian ibex habitat use.

268

269 In total, 11 habitat factors were considered: 1) We discarded a number of

270 variables with no statistical significance and avoided multicollinearity by using

271 the Spearman Rank Correlation coefficients. 2) Each of the independent

272 variables obtained from step 1 were then related to the dependent variable, 
273 ibex relative abundance. Stepwise multiple regression analysis was used

274 (Quinn and Keough 2002). 3) Variables that yielded $p<0.05$ in step 2 were

275 integrated into a final model which also included the nested factor of livestock

276 presence. We carried out a nested regression analysis and obtained a final

277 model through a backward stepwise procedure. The level of significance for

278 step 3 was set at 5\%. The statistics package used was SPSS 10.06.

279

280

281 RESULTS

282

283 Species distribution according to the surveys

284

285 Information covering $97.68 \%$ of the whole Castile - La Mancha region has

286 been obtained from 149 surveys correctly filled in. Results showed that the

287 Iberian ibex is present in $19 \%$ of the study area (175 out of 905 sampling

288 units). Five population nuclei have been identified: Montes de Toledo

289 mountain range, Sierra Madrona - Sierra Morena, Alto Tajo - Serranía de

290 Cuenca, Casas Ibáñez, and south of Albacete (see Figure 1). The species is

291 more widely distributed in Albacete province (it is present in $47 \%$ of the

292 territory), followed by Guadalajara (21\%), Cuenca (15\%), Ciudad Real (12\%)

293 and Toledo province (3\%).

294

295 Habitat suitability

296 
297 An habitat suitability map for the study species was carried out for the 298 province of Albacete, where the species was more abundant (see above).

299 This meant a total number of $15,3841 \times 1 \mathrm{~km}$. UTM grid cells. Table 1 shows 300 average values for the EGVs that define the habitat, both in the whole study 301 area (global mean) and in the area where ibexes were found (species mean, 302 with standardized values). For the ENFA analysis, the variable "average 303 distance to non-irrigated lands" was discarded due to its discontinuity. The 304 three significant factors selected (out of 27 ) explained $87.6 \%$ global 305 marginality and $75.2 \%$ global specialization. Coefficients of relationship 306 between variables and each one of the three factors are shown in Table 3.

308 Global marginality was 2.03 , and global tolerance was 0.49 . The habitat 309 suitability map can be seen in Figure 2. The first factor obtained, marginality 310 factor, was essentially associated to both high altitudes and slopes, and areas

311 distant to agro-forest lands, broadleaf woodlands, industrial areas, marshes

312 and vineyards (see coefficients in Table 3). Ibexes are extremely sensitive to

313 shifts from their optimal conditions on this axis. Next factors show a certain

314 degree of specialization, being associated to areas distant to coniferous

315 forests, sparse vegetation and human constructions, such as roads and

316 railways, but also close to annual crops lands. Factor 3 accounts for $19.2 \%$ of

317 specialization, so that information provided is much less accurate than that of 318 the other two factors (see Table 3). 
322 Relative ibex abundance was assessed by the largest size group registered in 323 each UTM grid cell considered in the study area, and obtained from the

324 questionnaire. Previously, we determined the validity of this measure by 325 relating it to our own average group size (see above). In our field surveys, we 326 detected 36 ibex groups (167 animals were counted) from the 17 transects 327 carried out in September 2003. The average group size was $4.76 \pm 0.65$, and 328 it correlated with the largest group size obtained in the questionnaire 329 (Spearman Rank Correlation: $n=9$, rho=0.80, $p=0.01$ ), so that the latter can be 330 considered as an estimate of ibex abundance.

332 Nested stepwise multiple regression analysis showed that livestock influences 333 habitat use of the Iberian ibex, relegating it to suboptimal vegetation areas 334 (see Table 4). In those grid cells where domestic goat livestock ranges in 335 sympatry with the ibex, the latter occupies preferentially cultivated lands, 336 sparse vegetation areas and forests; whereas in absence of livestock the ibex 337 is mainly found in pasture-scrub areas and non-cultivated lands. The marginal 338 effect caused by distance to goat livestock herds (see Factor 3 in Table 3), is 339 exemplified in Figure 2.

341 In Figure 3 the relationship between those variables which showed opposite 342 directions, depending on the presence/absence of goat livestock, i.e. scrub 343 land and cultures, is shown. 
348 Here we have updated the Iberian ibex distribution in the region of Castile - La

349 Mancha (central Spain). A habitat suitability model has also been

350 accomplished by using the ENFA technique, particularly suitable for presence-

351 only data of a given species. Our results indicate that the Iberian ibex is not

352 occupying its optimal habitat in those areas where it shares its range with

353 domestic goat herds.

354

355 On ibex distribution in the study region, it is noteworthy to point out a wider 356 presence in comparison with previous surveys (Alados 1997; Pérez et al.

357 2002). A plausible explanation is the expected increase of the species area of

358 distribution which is taking place nowadays, in part due to a natural increment

359 of population numbers due to habitat changes, game management

360 translocations (Gortazar et al. 2000) or its recovery from past sarcoptic mange

361 epizootics (Pérez et al. 1997), and a probable decrease of its hunting

362 pressure caused precisely by the incidence of this disease (see Garrido

363 2004).

364

365 Concerning risks associated to parasite infections of the ibex, the main agents 366 are host-inspecific, e.g. sarcoptic mange (Pérez et al. 1997), so that they can

367 infect any ungulate species, among other mammals. Therefore, at high host

368 densities, as it is the case in areas with high livestock densities, the availability

369 of habitat for these parasites increases, as does the risk of epizootics (see

370 Acevedo et al. 2005). 
372 Specific values for marginality and tolerance indexes are bound to depend on

373 the global set chosen as reference, so that a species might appear extremely

374 marginal or specialised on the scale of a whole country, but much less so a

375 subset of it (Hirzel et al. 2002). According to habitat suitability analysis carried

376 out the Iberian Ibex is highly marginal in the studied area, and presents a

377 medium tolerance, evidencing that, although it is placed in marginal areas in

378 Castile - La Mancha, it seems to tolerate habitat changes, therefore

379 compensating its marginality with the expansion to areas of relatively

380 suboptimal habitat.

381

382 In our study, livestock seem to compete and displace the Iberian ibex from its

383 optimal habitat, i.e. pasture-scrub lands (e.g. Chirosa et al. 2002), in those

384 grid cells where livestock is present (see Figure 2). We have no data on social

385 avoidance between both species, so that future research should be focused

386 on confirming this apparent ecological displacement. Similar conclusions were

387 obtained from a study carried out in the Great Basin, where pronghorn

388 (Antilocapra americana) avoided areas grazed by sheep during winter until

389 spring-regrowth occurred, and favoured areas temporarily rested from sheep

390 use (Clary and Holmgren 1982; Clary and Beale 1983).

392 This apparent displacement of the Iberian ibex to suboptimal habitats by

393 livestock presence is confirmed in our nested factor analysis of habitat use.

394 The results obtained indicate that the ibex occupies different habitats

395 depending on the presence of domestic goats. When they are present, as

396 seen in the previous analysis of habitat suitability, the ibex is preferentially 
found in suboptimal habitats, according to its resource requirements (see,

e.g., Chirosa et al. 2002), i.e. sparse vegetation, cultures and woodlands; whereas when livestock is absent, the ibex mainly uses scrub lands and non-

400 cultivated areas, where food availability according to its diet is higher (e.g.,

401 Martínez and Martínez 1987; Martínez 2000).

402

403 The question is whether both species, the ibex and the domestic goat, actually

404 compete for resources. Resource partitioning is defined as the differential use 405 by organisms of resources such as food and space (Schoener 1974; Begon et 406 al. 1996), and may explain how species coexist despite extensive overlap in 407 ecological requirements (Hutchinson 1959; MacArthur and Wilson 1967; 408 MacArthur 1972; May 1973). On the contrary, competition is considered to be 409 the major selective force causing this differential use of resources (Schoener $4101974 ; 1986)$.

412 As livestock range and distribution exceed any natural expansion process, 413 they can be considered as introduced exotic species (see, e.g., Voeten and 414 Prins 1999), and resource partitioning with native ungulates would not be 415 expected but, rather, a certain overlap in resource selection (see Fleischner 416 1994; Edwards et al. 1996; Aagesen 2000; Prins 2000). This is the case in

417 North American steppes, where livestock replaced the bison Bison bison and 418 pronghorn (Schwartz and Ellis 1981; Hartnett et al. 1997). Thus, dietary niche 419 divergence in sympatric species can occur even at a very subtle scale 420 (Hartnett et al. 1997). Campos-Arceiz et al. (2004) found that food overlap 421 between Mongolian gazelles (Procapra gutturosa) and livestock occurred not 
422

423 foraging.

424

425 Interpretation of measures of niche overlap in terms of the implications for

426 competitive interactions is problematic (Putman 1996). High observed overlap

427 can imply competition, but only if resources are limited. In fact, observations of

428 high overlap might equally well be indicative of a lack of competition (see

429 Schoener 1983; de Boer and Prins 1990; Putman 1996).

431 The implications these results may have on the Iberian ibex viability and

432 expansion can be evaluated from different views. Ibex populations in the

433 study region seem to be in expansion, particularly in the provinces of

434 Albacete, Cuenca and Guadalajara, if we compare current abundance of the

435 species (Figure 1) and that of former studies (e.g. Pérez et al. 2002).

436 Therefore, currently isolated populations might enter into contact. This may

437 imply new viability risks associated to the increase of certain diseases, such

438 as sarcoptic mange. This disease has already been detected sporadically in

439 Albacete province (C. Gortázar, unpublished data), so that a consequent

440 generalization of its prevalence might occur in the near future. Finally, hunting

441 pressure on the Iberian ibex is negligible in Castile - La Mancha: a 0.0004\%

442 (63 individuals) of total big game hunted in 1999-2003 period (Garrido 2004).

443 Therefore, we believe that game activity is not currently disturbing the Iberian

444 ibex expansion movements in the region. 
As a conclusion, we encourage comparative studies of habitat use with other

447 ungulate species in sympatry (including exotics), as well as a monitoring of

448 disease prevalence and colonization process in order to assure the

449 establishment of the species in central Spain.

450

451 ACKNOWLEDGEMENTS

452

453 We are grateful to Leticia Díaz for her useful comments on a previous version

454 of the manuscript as well as her advise on the statistical analyses. Two

455 anonymous referees also contributed to the improvement of the manuscript.

456 We are also indebted to M. Martínez, V. Alzaga, J. Millán, A. Pérez and J.

457 Vicente for assistance in the field. This research was supported by a JCCM-

458 CAMA agreement. Pde Asturias and CSIC. J.C. is currently supported by the

459 Ministerio de Educación y Ciencia and CSIC through a Ramón y Cajal

460 contract.

REFERENCES

464

465 Aagesen, D. (2000). Crisis and conservation at the end of the world: sheep

466 ranching in Argentine Patagonia. Environmental Conservation 27: 208-215.

467

468 Acevedo, P., Vicente, J., Alzaga, V. and Gortázar, C. 2005. Relationship

469 between bronchopulmonary nematode larvae and relative abundances of 
470 Spanish ibex (Capra pyrenaica hispanica) from Castilla - La Mancha, Spain.

$471 \quad J$. Helminthol. 79: 113-118.

472

473 Alados, C.L. (1986). Time distribution of activities in the Spanish ibex, Capra

474 pyrenaica. Biol. Behav. 11: 70-82.

475

476 Alados, C.L. (1997). Status and distribution of Caprinae by region. Spain. In

477 Wild sheep and goats and their relatives: 125-130. Shackleton, D.M. (Ed.).

478 Cambridge, UK: IUCN.

479

480 Alados, C. and Escós, J. (1996). Ecología y comportamiento de la cabra 481 montés. Consideraciones para su gestión. Monografías del Museo Nacional 482 de Ciencias Naturales. Madrid: Consejo Superior de Investigaciones 483 Científicas.

484

485 Araujo, M.B., Thuiller, W., Williams, P.H. and Reginster, I. (2005).

486 Downscaling European species atlas distributions to a finer resolution:

487 implications for conservation planning. Global Ecol. Biogeogr. 14: 17-30.

488

489 Austin, M.P. (2002). Spatial prediction of species distribution: an interface

490 between ecological theory and statistical modeling. Ecol. Model. 157: 101-

491118

492

493 Begon, M., Harper, J.L. and Townsend, C.R. (1996). Ecology: individuals, 494 populations and communities. 3rd edn. Oxford: Blackwell Science. 
496 Braza, F. (2002). Dama dama Linnaeus, 1758. Gamo. In Atlas de los

497 mamíferos terrestres de España: 314-317. Palomo, L.J. and Gisbert, J. (Eds.).

498 Madrid: Dirección General de Conservación de la Naturaleza, SECEM,

499 SECEMU.

500

501 Brito, J.C., Crespo, E.G. and Paulo, O.S. (1999). Modelling wildlife

502 distributions: Logistic Multiple Regression vs Overlap Analysis. Ecography 22:

$503 \quad 251-260$.

504

505 Brotons, L., Thuiller, W., Araujo, M.B. and Hirzel A.H. (2004). Presence-

506 absence versus presence-only based habitat suitability models for bird atlas

507 data: the role of species ecology and prevalence. Ecography 27: 285-298

508

509 Burnham, K.P., Anderson, D.R. and Laake, J.L. (1980). Estimation of density

510 from line transect sampling of biological populations. Wildl. Monogr. 72: 1-202.

511

512 Campos-Arceiz, A., Takatsuki, S. and Lhagvasuren, B. (2004). Food overlap

513 between Mongolian gazelles and livestock in Omnogobi, southern Mongolia.

514 Ecol. Res. 19: 455-460.

515

516 Carranza, J. (2002). Cervus elaphus Linnaeus, 1758. Ciervo rojo. In Atlas de

517 los mamíferos terrestres de España: 310-313. Palomo, L.J. and Gisbert, J.

518 (Eds.). Madrid: Dirección General de Conservación de la Naturaleza, SECEM,

519 SECEMU. 
521 Cassinello, J., Serrano, E., Calabuig, G. and Pérez, J.M. (2004). Range

522 expansion of an exotic ungulate (Ammotragus lervia) in southern Spain:

523 Ecological and conservation concerns. Biodivers. Conserv. 13: 851-866.

524

525 Chefaoui, R.M., Hortal, J. and Lobo, J.M. (2005). Potential distribution

526 modelling, niche characterization and conservation status assessment using

527 GIS tools: a case study of Iberian Copris species. Biol. Conserv. 122: 327-

528338.

529

530 Chirosa, M., Delibes-Senna, J.R., Fandos, P., Granados, J.E., Pérez, M.C.,

531 Pérez, J.M., Ruiz-Martínez, I., Serrano, E., Soriguer, R.C. and Weykam, S.

532 (2002). Estimas poblacionales de Capra pyrenaica hispanica. In Distribución,

533 genética y estatus sanitario de las poblaciones andaluzas de cabra montés:

534 1-68. Pérez, J.M. (Ed.). Sevilla: Junta de Andalucía, Consejería de Medio

535 Ambiente.

536

537 Clary, W.P. and Beale, D.M. (1983). Pronghorn reactions to winter sheep

538 grazing, plant communities, and topography in the Great Basin. J. Range

539 Manage. 36: 749-752.

540

541 Clary, W.P. and Holmgren, R.C. (1982). Observations of pronghorn

542 distribution in relation to sheep grazing on the Desert Experimental Range. In

543 Wildlife-livestock relationships symposium: 581-592. Peek, J.M. and Dalke, 
544 P.D. (Eds.). Moscow, Idaho: University of Idaho, Forest, Wildlife, and Range

545 Experiment Station.

546

547 de Boer, W. F. and Prins, H. H. T. (1990). Large herbivores that strive mightily

548 but eat and drink as friends. Oecologia 82: 264-274.

549

550 Edwards, G.P., Croft, D.B. and Dawson, T.J. (1996). Competition between red

551 kangaroo (Macropus rufus) and sheep (Ovis aries) in the arid rangelands of

552 Australia. Aust. J. Ecol. 21: 165-172.

553

554 Engler, R., Guisan, A. and Rechsteiner, L. (2004). An improved approach for

555 predicting the distribution of rare and endangered species from occurrence

556 and pseudo-absence data. J. Appl. Ecol. 41: 263-274.

557

558 European Environment Agency (1996). Natural resources. CD-Rom,

559 European Environment Agency, Copenhagen, Denmark.

560

561 European Environment Agency (2000). Natural resources. CD-Rom,

562 European Environment Agency, Copenhagen, Denmark.

563

564 Ferrier, S., Watson, G., Pearce, J. and Drielsma, M. (2002). Extended

565 statistical approaches to modelling spatial pattern in biodiversity in northeast

566 New South Wales. I. Species-level modelling. Biodivers. Conserv. 11: 2275-

5672307.

568 
569 Fleischner, T.L. (1994). Ecological costs of livestock grazing in Western North

570 America. Conserv. Biol. 8: 629-644.

571

572 Gallego, D., Cánovas, F., Esteve, M.A. and Galián, J. (2004). Descriptive

573 biogeography of Tomicus (Coleoptera: Scolytidae) species in Spain. J.

574 Biogeogr. 31: 2011-2024.

575

576 Garrido, J.L. (2004). Aprovechamientos por especies y autonomías. II Máster

577 en Conservación y Gestión de los Recursos Cinegéticos. Ciudad Real, marzo

578 2004. Unpublished report.

579

580 Gortazar, C., Herrero, J., Villafuerte, R. and Marco, J. (2000). Historical

581 examination of the distribution of large mammals in Aragón, Northeastern

582 Spain. Mammalia 61: 411-422.

583

584 Granados, J. E. (2001). Distribución y estatus de la cabra montés (Capra

585 pyrenaica, Schinz 1838) en Andalucía. PhD Thesis. Universidad de Jaén.

586

587 Granados, J.E., Chirosa, M., Pérez, M.C., Pérez, J.M., Ruiz Martínez, I.,

588 Soriguer, R.C. and Fandos, P. (1998). Distribution and status of the Spanish

589 ibex Capra pyrenaica in Andalusia, Southern Spain. Proccedings of the 2nd

590 World Conference of Mountain Ungulates, Aosta: 129-133.

591

592 Granados, J.E., Soriguer, R.C., Pérez, J.M., Fandos P. and García-Santiago,

593 J. (2002). Capra pyrenaica Schinz, 1838. In Atlas de los mamíferos terrestres 
de España: 326-329. Palomo, L.J. and Gisbert, J. (Eds.). Madrid: Dirección

595 General de Conservación de la Naturaleza, SECEM, SECEMU.

596

597 Guisan, A. and Zimmermann, N.E. (2000). Predictive habitat distribution

598 models in ecology. Ecol. Model. 135: 147-186.

599

600 de Haan, C., Steinfeld, H. and Blackburn, H. (1997). Livestock and the

601 environment: finding a balance. Report of a Study Coordinated by FAO /

602 World Bank / USAID.

603

604 Hartnett, D. C., Steuter, A. A. and Hickman, K. R. (1997). Comparative

605 ecology of native and introduced ungulates. In Ecology and conservation of

606 great plains vertebrates: 72-101. Knopf, F.L. and Samson, F.B. (Eds.). New

607 York: Springer.

608

609 Hirzel, A. 2001. Linking landscape and population ecology for large population

610 management modelling: the case of Ibex (Capra ibex) in Switzerland. PhD

611 Thesis, Université de Lausanne.

612 <http://www2.unil.ch/biomapper/Download/hirzel-2001-phd.zip>

613

614 Hirzel, A.H., Hausser, J., Chessel, D. and Perrin, N. (2002). Ecological-niche

615 factor analysis: how to compute habitat-suitability maps without absence

616 data? Ecology 83: 2027-2036.

617 
618 Hirzel, A.H., Helfer, V. and Metral, F. (2001). Assessing habitat suitability

619 models with a virtual species. Ecol. Model. 145: 111-121.

620

621 Hirzel, A.H., Posse, B., Oggier, P.-A., Crettenand, Y., Glenz, C. and Arlettaz,

622 R. (2004). Ecological requirements of reintroduced species and the

623 implications for release policy: the case of the bearded vulture. J. Appl. Ecol.

624 41: 1103-1116.

625

626 Hortal, J., Borges, P.A.V., Dinis, F., Jiménez-Valverde, A., Chefaoui, R.M.,

627 Lobo, J.M., Jarroca, S., Brito de Azevedo, E., Rodrigues, C., Madruga, J.,

628 Pinheiro, J., Gabriel, R., Cota Rodrigues, F. and Pereira, A.R. (2005) Using

629 ATLANTIS - Tierra 2.0 and GIS environmental information to predict the 630 spatial distribution and habitat suitability of endemic species. In A list of the

631 terrestrial fauna (Mollusca and Arthropoda) and flora (Bryophyta, Pteridophyta

632 and Spermatophyta) from the Azores: 69-113. Borges, P.A.V., Cunha, R.

633 Gabriel, R., Martins, A.F., Silva, L. and Vieira, V. Horta, Angra do Heroísmo

634 and Ponta Delgada: Direcção Regional de Ambiente and Universidade dos 635 Açores.

636

637 Hortal, J., Lobo, J.M. and Martín-Piera, F. (2001). Forecasting insect species

638 richness scores in poorly surveyed territories: the case of the Portuguese

639 dung beetles (Col. Scarabaeinae). Biodivers. Conserv. 10: 1343-1367.

640

641 Hutchinson, G.E. (1959). Homage to Santa Rosalia or why are there so many

642 kinds of animals? Am. Nat. 93: 145-159. 
644 IUCN (2004). 2004 IUCN red list of threatened species. <www.redlist.org>.

645 Downloaded on 26 January 2005.

646

647 Lasso De La Vega, B. (1994). Estimación de la población de cabra montés en

648 Sierra Tejeda y Almijara (Málaga). In Actas del I Congreso Internacional del

649 Género Capra en Europa: 217-218. Ronda: Consejería de Medio Ambiente,

650 Junta de Andalucía.

651

652 Lodge, D. M. (1993). Biological invasions: lessons for ecology. Trends Ecol.

653 Evol. 8: 133-137.

654

655 MacArthur, R.H. (1972). Geographical ecology: patterns in the distribution of 656 species. New York: Harper Row.

657

658 MacArthur, R.H. and Wilson, E.O. (1967). The theory of island biogeography.

659 Princeton: Princeton University Press.

660

661 Madhusudan, M.D. (2004). Recovery of wild large herbivores following

662 livestock decline in a tropical Indian wildlife reserve. J. Appl. Ecol. 41: 858663869.

664

665 Manceau, V., Crampe, J.-P., Boursot, P. and Taberlet, P. (1999). Identification

666 of evolutionary significant units in the Spanish wild goat, Capra pyrenaica

667 (Mammalia, Artiodactyla). Anim. Conserv. 2: 33-39. 
669 Martín Bellido, M., Escribano Sánchez, M., Mesías Díaz, F.J., Rodríguez de

670 Ledesma Vega, A. and Pulido García, F. (2001). Sistemas extensivos de

671 producción animal. Arch. Zootec. 50: 465-489.

672

673 Martínez, T. (2000). Diet selection by Spanish ibex in early summer in Sierra

674 Nevada. Acta Theriol. 45: 335-346.

675

676 Martínez, T. (2002). Summer feeding strategy of Spanish ibex Capra

677 pyrenaica and domestic sheep Ovis aries in south-eastern Spain. Acta

678 Theriol. 47: 479-490.

679

680 Martínez, T. and Martínez, E. (1987). Diet of Spanish wild goat, Capra

681 pyrenaica, in spring and summer at the Sierra de Gredos, Spain. Mammalia $682 \quad 51: 547-557$.

683

684 May, M.R. (1973). Stability and complexity in model ecosystems. Princeton:

685 Princeton University Press.

686

687 Mishra, C. and Rawat, G.S. (1998). Livestock grazing and biodiversity

688 conservation: comments on Saberwal. Conserv. Biol. 12: 712-714.

689

690 Osborne, P.E. and Tigar, B.J. (1992). Interpreting bird atlas using logistic

691 models: an example from Lesotho, Southern Africa. J. Appl. Ecol. 29: 55-62. 
693 Palomares, F. and Ruiz Martínez, I. (1993). Status and conservation

694 perspectives for the Spanish ibex population of Sierra Mágina Natural Park, 695 Spain. Z. Jagdwiss. 39: 87-94.

696

697 Pérez, J.M., Granados, J.E. and Soriguer, R.C. (1994). Population dynamic of 698 the Spanish ibex Capra pyrenaica in Sierra Nevada Natural Park (southern 699 Spain). Acta Theriol. 39: 289-294.

700

701 Pérez, J.M., Granados, J.E., Soriguer, R.C., Fandos, P., Marquez, F.J. and 702 Crampe, J.P. (2002). Distribution, status and conservation problems of the 703 Spanish Ibex, Capra pyrenaica (Mammalia : Artiodactyla). Mammal Rev. 32: $704 \quad 26-39$.

705

706 Pérez, J.M., Ruiz, I., Granados, J.E., Soriguer, R.C. and Fandos, P. (1997).

707 The dynamics of sarcoptic mange in the ibex population of Sierra Nevada in 708 Spain: Influence of climatic factors. J. Wildl. Res. 2: 86-89.

709

710 Price, E.O. (2002). Animal domestication and behavior. Wallingford, New

711 York: CABI Publishing.

712

713 Prins, H.H.T. (2000). Competition between wildlife and livestock in Africa. In

714 Wildlife conservation by sustainable use: 51-80. Prins, H.H.T., Grootenhuis, 715 J.G. and Dolan, T.T. (Eds.). Boston, MA: Kluwer Academic Publishers. 
717 Putman, R. J. (1996). Competition and resource partitioning in temperate

718 ungulate assemblies. London: Chapman and Hall.

719

720 Quevedo, M., Bañuelos, M.J. and Obeso, J.R. (2006). The decline of

721 Gantabrian capercaille: How much does habitat configuration matter. Biol.

722 Gonserv. 127: 190-200.

723

724 Quinn, G.P. and Keough, M.J. (2002). Experimental design and data analysis

725 for biologists. Cambridge: Cambridge University Press.

726

727 Reutter, B.A., Helfer, V., Hirzel, A.H. and Vogel, P. (2003). Modelling habitat-

728 suitability using museum collections: an example with three sympatric

729 Apodemus species from the Alps. J. Biogeogr. 30: 581-590.

730

731 Rosell, C. and Herrero, J. (2002). Sus scrofa Linnaeus, 1758. Jabalí. In Atlas

732 de los mamíferos terrestres de España: 306-309. Palomo, L.J. and Gisbert, J.

733 (Eds.). Madrid: Dirección General de Conservación de la Naturaleza, SECEM, 734 SECEMU.

735

736 Rushton, S.P., Ormerod, S.J. and Kerby, G. (2004). New paradigms for

737 modelling species distributions? J. Appl. Ecol. 41: 193-200.

738

739 Saberwal, V.K. (1996). Pastoral politics: gaddi grazing, degradation, and

740 biodiversity conservation in Himachal Pradesh, India. Conserv. Biol. 10: 741-

741749. 
743 San José, C. (2002). Capreolus capreolus Linnaeus, 1758. Corzo. In Atlas de

744 los mamíferos terrestres de España: 318-321. Palomo, L.J. and Gisbert, J.

745 (Eds.). Madrid: Dirección General de Conservación de la Naturaleza, SECEM,

746 SECEMU.

747

748 Schoener, T.W. (1974). Competition and the form of habitat shift. Theor.

749 Popul. Biol. 6: 265-307.

750

751 Schoener, T. W. (1983). Field experiments on interspecific competition. Am.

752 Nat. 122: 240-285.

753

754 Schoener, T.W. (1986). Resource partitioning. In Community ecology, pattern

755 and process: 91-126. Kikkawa, J. and Anderson, D.J. (Eds.). Oxford:

756 Blackwell.

757

758 Schwartz, C. and Ellis, J. E. (1981). Feeding ecology and niche separation in 759 some native and domestic ungulates on the shortgrass prairie. J. Appl. Ecol. 760 18: 343-353.

761

762 Sokal, R.R. and Rohlf, F. J. (1981). Biometry. 2nd edn. San Francisco: W.H.

763 Freeman and Company.

764 
765 Scott, J.M., Heglund, P.J., Haufler, J.B., Morrison, M., Raphael, M.G., Wall, 766 W.B. and Samson, F. (Eds.) (2002). Predicting species occurrences: Issues of

767 accuracy and scale. Covelo, California: Island Press.

768

769 Thuiller, W., Brotons, L., Araujo, M.B. and Lavorel, S. (2004). Effects of

770 restricting environmental range data to project current and future species

771 distributions. Ecography 27: 165-172.

772

773 Toigo, C, Gaillard, J.M. and Michallet, J. (1996). La taille des groupes: un

774 bioindicateur de l'effectif des populations de bouquetin des Alpes (Capra ibex

775 ibex)?. Mammalia 60: 463-472.

776

777 Troy, C.S., MacHugh, D.E., Bailey, J.F., Magee, D.A., Loftus, R.T.,

778 Cunningham, P., Chamberlain, A.T., Sykes, B.C. and Bradley, D.G. (2001).

779 Genetic evidence for Near-Eastern origins of European cattle. Nature 410:

$780 \quad 1088-1091$.

781

782 Voeten, M.M. and Prins, H.H.T. (1999). Resource partioning between

783 sympatric wild and domestic herbivores in the Tarangire region of Tanzania.

784 Oecologia 120: 287-294.

785

786 Whittaker, R.J., Araujo, M.B., Paul, J., Ladle, R.J., Watson, J.E.M. and Willis,

787 K.J. (2005). Conservation Biogeography: assessment and prospect. Divers.

788 Distrib. 11: 3-23.

789 
790 Young, T.P., Palmer, T.M. and Gadd, M.E. (2005). Competition and

791 compensation among cattle, zebras, and elephants in a semi-arid savanna in

792 Laikipia, Kenya. Biol. Conserv. 122: 351-359.

793

794 Zaniewski, A.E., Lehmann, A. and Overton, J.M. (2002). Predicting species

795 spatial distributions using presence-only data: a case study of native New

796 Zealand ferns. Ecol. Model. 157: 261-280.

797 


\section{FIGURE LEGENDS}

799

800 Figure 1. Situation of the study area (Castile - La Mancha region in central

801 Spain), the administrative provinces concerned, and its division in $10 \times 10$

802 grids, showing the presence/absence of the Iberian ibex.

803

804 Figure 2. Habitat suitability map for the Iberian ibex in Albacete province.

805 Observed Ibex distribution is outlined. The arrow indicates a potentially

806 suitable area not occupied by the ibex, and where livestock is present.

807

808 Figure 3. Relationships between Iberian ibex relative abundance and two

809 EGVs which show opposite directions depending on the presence/absence of

810 goat livestock, i.e. scrub land and cultures (see Table 4).

811 
812 Table 1. Ecogeographical variables (EGVs) used in the ENFA. Average

813 values in the study region are shown (global mean), together with the

814 standardized ones, as provided by ENFA, in areas where the Iberian ibex is

815 present (species mean). All values are in metres, except for orientation, which

816 is in degrees.

\begin{tabular}{|c|c|c|c|}
\hline Codes & Meaning & $\begin{array}{l}\text { Global } \\
\text { mean }\end{array}$ & $\begin{array}{c}\text { Species } \\
\text { mean }\end{array}$ \\
\hline \multicolumn{4}{|l|}{ TOPOGRAFIC } \\
\hline altitud_max & Maximum altitude & 507.24 & 0.95 \\
\hline aspect & Average orientation & 98.49 & 0.87 \\
\hline slope & Average slope & 2.82 & 1.44 \\
\hline \multicolumn{4}{|l|}{ CULTURES } \\
\hline dist_agriculture & Average distance to cultivated lands & 2260.56 & 0.82 \\
\hline dist_agroforest & Average distance to agroforest lands & 11990.41 & 1.22 \\
\hline dist annual crops & Average distance to annual crops & 19572.28 & 0.63 \\
\hline dist_complex_cult & Average distance to complex cultures & 1933.19 & 0.64 \\
\hline dist_perm_irrigate & Average distance to irrigated cultures & 1368.97 & 0.42 \\
\hline \multicolumn{4}{|l|}{ FRUIT TREE } \\
\hline dist_fruit_tree & Average distance to fruit tree cultures & 4249.16 & 0.15 \\
\hline dist_olives & Average distance to olive tree cultures & 5388.66 & 0.04 \\
\hline dist_vinēyards & Average distance to vineyards & 4714.15 & 1.25 \\
\hline \multicolumn{4}{|l|}{ WOODLAND } \\
\hline dist_broad_leav & Average distance to broad leaves forests & 4828.36 & 1.05 \\
\hline dist mixed forest & Average distance to mixed forests & 6194.78 & 0.72 \\
\hline dist_connifeous & Average distance to conniferous forests & 3021.63 & -0.34 \\
\hline dist_wood_scrub & Average distance to wood-scrub ecotones & 1509.38 & 0.81 \\
\hline dist_sclerophyllous & Average distance to sclerophyllous areas & 1421.79 & 0.34 \\
\hline \multicolumn{4}{|l|}{ SCRUBLAND } \\
\hline $\begin{array}{l}\text { dist_moors_heath } \\
\text { GRASSLAND }\end{array}$ & Average distance to moors and heaths areas & 29133.07 & 0.56 \\
\hline $\begin{array}{l}\text { dist_natu_grass } \\
\text { SPARSE VEG. }\end{array}$ & Average distance to natural grass lands & 2706.51 & 0.39 \\
\hline dist_sparse_veg & Average distance to sparse vegetation & 12196.57 & -0.32 \\
\hline dist_bare_rocks & Average distance to bare rocks areas & 24583.19 & -0.05 \\
\hline \multicolumn{4}{|l|}{ INFRASTRUCTURE } \\
\hline dist_village & Average distance to villages & 3217.65 & 0.84 \\
\hline dist_industr & Average distance to industrial areas & 11612.99 & 1.07 \\
\hline dist_road_rail & Average distance to roads and rails & 27601.89 & 0.74 \\
\hline \multicolumn{4}{|l|}{ WATER } \\
\hline dist_river & Average distance to rivers & 10852.34 & -0.09 \\
\hline dist_inland_marshes & Average distance to inland marshes & 20417.79 & 1.38 \\
\hline dist_water_bodies & Average distance to water bodies & 14409.52 & 0.09 \\
\hline LIVESTOCK & & & \\
\hline dist_goat_livestock & Average distance to goat livestock & 2515.05 & 0.07 \\
\hline
\end{tabular}

817 
819 Table 2. EGVs used in habitat use analysis for the Iberian ibex relative

820 abundance dependent variable. The significance level of step 2 is provided (**

$821 p<0.01,{ }^{*} p<0.05$, n.s. = non-significant). See text and Table 1 for more 822 details.

\begin{tabular}{lcc}
\hline \multicolumn{1}{c}{ Variables } & Meaning & Significance \\
\hline Goat livestock & Presence/Absence of goat livestock & $* *$ \\
Highest altitude & Maximum altitude $(\mathrm{m})$ & n.s. \\
Average altitude & Average altitude $(\mathrm{m})$ & n.s. \\
Slope & Average slope index & n.s. \\
Cultures & Frequency of cultures per pixel & $*$ \\
Woodland & Frequency of woodlands per pixel & $* *$ \\
Scrubland & Frequency of scrublands per pixel & $* *$ \\
Grassland & Frequency of grasslands per pixel & n.s. \\
Sparse vegetation & Frequency of sparse vegetations per pixel & $* *$ \\
Infrastructures & Frequency of human infrastructures per pixel & n.s. \\
Water reservoir & Frequency of rivers per pixel & $*$ \\
\hline
\end{tabular}

823

824 
825 Table 3. Correlation between ENFA factors and the environmental descriptors

826 (EGVs). Percentages indicate the amount of specialization accounted for by

827 each factor. Factor 1 is Marginality factor.

828

\begin{tabular}{lccc}
\hline \multicolumn{1}{c}{ Variable } & $\begin{array}{c}\text { Factor } 1 \\
(87.6 \%)\end{array}$ & $\begin{array}{c}\text { Factor } 2 \\
(55.4 \%)\end{array}$ & $\begin{array}{c}\text { Factor } 3 \\
(19.2 \%)\end{array}$ \\
\hline altitud_max & 0.24 & 0.01 & 0.10 \\
aspect & 0.22 & 0.04 & 0.00 \\
dist_agriculture & 0.21 & 0.08 & -0.02 \\
dist_agro_forest & 0.31 & -0.09 & 0.32 \\
dist_annual_crops & 0.16 & -0.26 & 0.16 \\
dist_broad_leav & 0.26 & -0.02 & 0.00 \\
dist_goat_livestock & 0.02 & -0.06 & 0.20 \\
dist_coniferous & -0.09 & 0.51 & 0.61 \\
dist_industr & 0.27 & 0.09 & 0.23 \\
dist_inland_marshes & 0.35 & -0.02 & -0.37 \\
dist_road_rail & 0.19 & 0.42 & 0.11 \\
dist_sparse_veg & -0.08 & 0.62 & -0.27 \\
dist_villages & 0.21 & -0.09 & 0.04 \\
dist_vineyards & 0.31 & 0.12 & -0.14 \\
dist_water_bodies & 0.02 & 0.03 & -0.34 \\
dist_wood_scrub & 0.20 & -0.01 & -0.01 \\
slope & 0.36 & 0.04 & 0.01 \\
\hline
\end{tabular}

829

830

831 
832 Table 4. Final model obtained for the habitat use analysis for the Iberian ibex 833 relative abundance dependent variable (nested stepwise regression output).

834 GL column refers to goat livestock absence $(A)$ and presence $(P)$. T.E. refers 835 to the typical error. Significance relationships are in bold.

\begin{tabular}{cccccc}
\hline Parameter & GL & Estimate & T.E. & $\mathrm{t}$ & Probability \\
\hline Intercept & & 3.07 & 0.86 & 3.58 & $<0.01$ \\
& & & & & \\
Scrub land & (A) & 0.88 & 0.31 & 2.88 & $<0.01$ \\
& (P) & -0.94 & 0.30 & -3.13 & $<0.01$ \\
Cultures & (A) & -0.53 & 0.27 & -2.47 & 0.01 \\
& (P) & 0.89 & 0.19 & 4.67 & $<0.01$ \\
Wood land & (A) & -0.04 & 0.22 & -0.20 & 0.84 \\
& (P) & 0.81 & 0.22 & 3.65 & $<0.01$ \\
Sparse vegetation & (A) & -0.27 & 3.10 & -0.09 & 0.93 \\
& (P) & 1.45 & 0.45 & 3.19 & $<0.01$ \\
Water & (A) & 5.62 & 4.02 & 1.40 & 0.16 \\
& (P) & 12.55 & 6.14 & 2.04 & 0.04 \\
Goat livestock & (A) & -4.54 & 1.23 & -3.69 & $<0.01$ \\
& (P) & 0 & 0.00 &. &. \\
\hline
\end{tabular}

836 

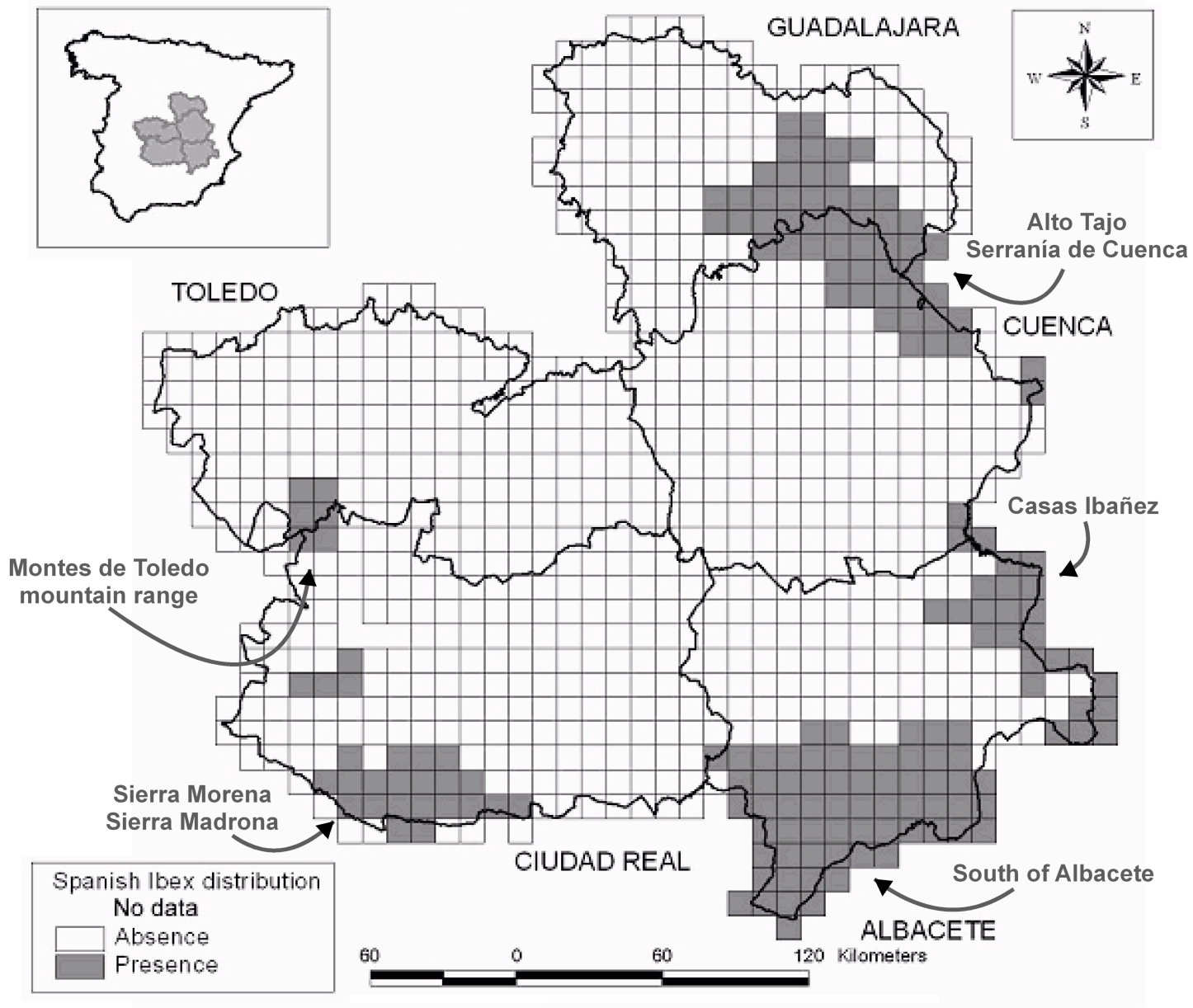

838

839

840

FIGURE 1

841

842 


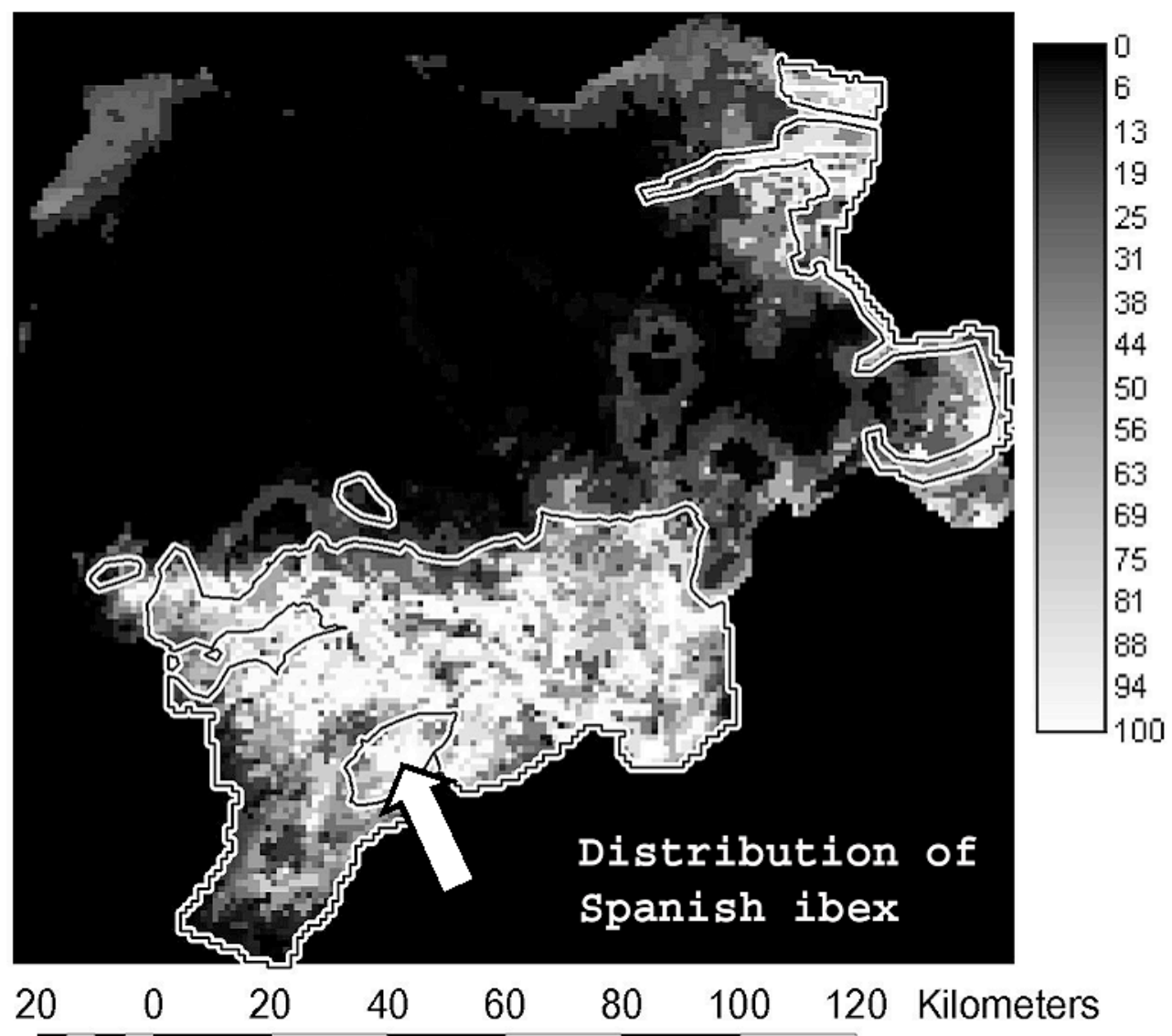

843

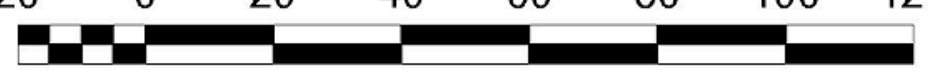

844

845

FIGURE 2

846 

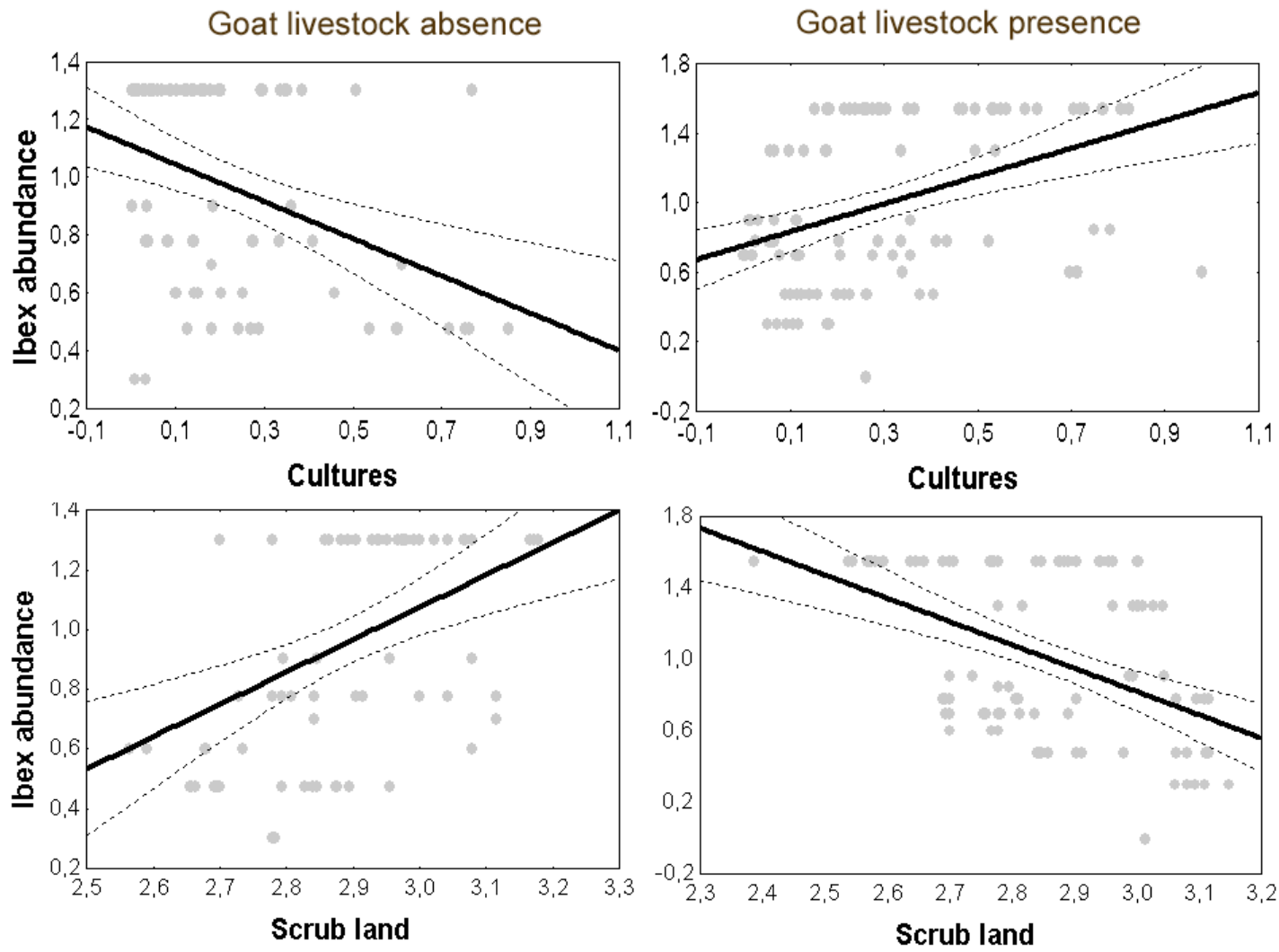